\title{
РЕЦЕНЗИЯ НА СБОРНИК НАУЧНЫХ СТАТЕЙ СОЦИОЛИНГВИСТИЧЕСКИЕ ИССЛЕДОВАНИЯ В ТЕОРИИ И ПРАКТИКЕ: МЕЖДИСЦИПЛИНАРНЫЙ ПОДХОД (ГДАНЬСК 2018)
}

(получено 15.10.2018; принято 17.11.2018)

Современное языкознание, далеко вышедшее за пределы собственного методологического аппарата и синхронического описания строго лингвистических фактов и факторов, активно простирает свои интересы на проблемы, носящие комплексный характер и имеющие отношение к другим наукам гуманитарного блока. И это неслучайно: происходящие в социально-экономическом и общественно-культурном поле перемены и связанные с ними процессы перераспределения актуальных межгосударственных и межнациональных точек соприкосновения со всей очевидностью говорят о необходимости изучения и описания многообразных социокультурных трансформаций лингвистического и коммуникационного уровней, приводящих к появлению новых тенденций в пространстве текста / дискурса и (как результат) - к обновлению языковой картины мира.

Будучи амбивалентной по своей природе - самым устойчивым и одновременно самым диффузным субстратом универсума, - иерархически организованная система любого естественного (этнического) языка сегодня оказывается областью синергии как общетеоретических, так и практико-ориентированных научных направлений, раскрывающих различные стороны речевой деятельности и вербального поведения в целом. Особое место в данном исследовательском процессе, безусловно, принадлежит социолингвистике - области интеграции антропоцентрического, когнитивно-семиотического и коммуникативно-прагматического подходов к анализу фактов функционирования языка, позволяющей наиболее достоверно фиксировать многоплановые преобразования в системе человеческого мировосприятия и взаимодействия.

В этой связи актуальность рецензируемого сборника научных статей несомненна: лингвоцентрическое осмысление ценностно-идеологических доминант разнокодовых и разножанровых текстов требует высокой метаязыковой воору- 
женности, невозможной без характеризации онтологической сущности и специфических признаков конституентов современных социальных интеракций. Системный анализ базисных компонентов коммуникативных практик обеспечивается наличием в сборнике трех пересекающихся разделов: лингвострановедение и диалектология, актуальные дискурсы, лингвистические исследования в образовательном аспекте, тем самым задается научное поле, предполагающее синтез социологии, семасиологии, лингвокультурологии, коммуникологии и собственно языкознания.

Несомненным достоинством рецензируемого сборника является разноплановость тематического поля статей. Так, значительный интерес представляют работы, освещающие когнитологические параметры текстовых единиц - дихотомию репрезентации языкового и психологического, механизмы концептуализации знака, аксиологические маркеры (М. Ящевска, И. Ольшевска, М. Ноиньска, К. Велондек). Не менее интересными являются научные воззрения авторов на современные речевые реалии - семантико-функциональную адаптацию заимствований в условиях транслингвального пространства, компаративный анализ способов трансляции вербальных знаков, особенности лексико-стилистической экспликации языковых единиц, эколингвистические проблемы (И. Антоненко, Е. Воячек, Ж. Сладкевич, Т. Копац, Д. Станулевич). Лингвометодический блок рецензируемого сборника демонстрирует не только прагматико-дидактическую ориентированность работ, но и их существенную теоретическую составляющую: от анализа психомыслительной деятельности индивида как основы применения знаний в новой коммуникативной среде, описания новаций в методике преподавания иностранного языка до выявления особенностей межкультурной коммуникации - как в самом широком, полиэтническом, так и в конкретном, межличностном смысле (Е. Петрась, М. Марцишевска, Л. Овчинникова и И. Мампе, А. Хау и К. Вондоловска-Леснер). Скрепой же всего представленного корпуса статей следует считать их направленность на решение актуальнейшей для мирового образовательного пространства задачи - повышение общей и профессиональной компетентности обучающихся и их дальнейшую самореализацию.

Рецензируемый сборник, несомненно, имеет практическую ценность: методологические основания междисциплинарного исследования современного информационного общества могут быть корректно экстраполированы на другие языковые явления (парадигматически или синтагматически соотносимые), а результаты представленных исследований, бесспорно, найдут применение в преподавании курсов и спецкурсов по социолингвистике, лингвокультурологии, компаративистике, типологическому языкознанию и в лексикографической и ортологической практике.

В целом предлагаемое научное издание демонстрирует современную парадигму лингвистического знания, интегрирующую разносторонние и разноуровневые вопросы теории и практики языка и смежных с ними отраслей, определяет вектор дальнейшего творческого поиска ученых в гуманитарной области и несомненно будет интересно и полезно научным работникам, преподавате- 
лям, обучающимся языковых вузов, практикующим переводчикам, широкой педагогической общественности.

\section{НАТАЛЬЯ БОЖЕНКОВА}

Государственный институт русского языка им. А. С. Пушкина

Кафедра общего и русского языкознания

ул. Академика Волгина 6, Москва, 117485, Россия

e-mail: nabozhenkova@pushkin.institute

ORCID: https://orcid.org/0000-0002-2381-5865 